\title{
A comparison of North American and West European infaunal amphipod species in a toxicity test on North Sea sediments
}

\author{
Peter van den Hurk ${ }^{1}$, Peter M. Chapman ${ }^{2}$, Brian Roddie ${ }^{3 r^{*}}$, \\ Richard C. Swartz ${ }^{4}$ \\ ${ }^{1}$ Bureau Waardenburg bv, PO Box 365, 4100 AJ Culemborg, The Netherlands \\ ${ }^{2}$ EVS Consultants, 195 Pemberton Avenue, N. Vancouver, British Columbia, Canada V7P 2R4 \\ ${ }^{3}$ Water Research Centre, Medmenham Laboratory, PO Box 16, Marlow, Buckinghamshire SL7 2HD, United Kingdom \\ ${ }^{4}$ Marine Science Center, U.S. Environmental Protection Agency, Newport, Oregon 97365, USA
}

\begin{abstract}
During the Bremerhaven Workshop, sediment samples from 2 pollution gradients in the North Sea were tested in a $10 \mathrm{~d}$ static bioassay with infaunal amphipods. One gradient was downstream from a former drilling site, the second was offshore of the Elbe-Weser plume in the German Bight. Four participating laboratories used basically the same technique to test sediment toxicity with 1 of 3 different amphipod species: Rhepoxynius abronius, Corophium volutator or Bathyporeia sarsi. The measured endpoints were mortality and sublethal effects, including the inability to reburrow after exposure, avoidance and immobilisation. Results show that sediment samples from the stations on each gradient closest to contaminant sources were toxic to nearly all test species. Samples from other stations only caused mortality in the tests with $C$. volutator.
\end{abstract}

\section{INTRODUCTION}

The alm of the Bremerhaven Workshop was to test and compare available biological effects monitoring techniques for marine pollution. Two areas of the North Sea with known gradients of contamination were selected for study: a transect in the German Bight, running northwest from the outflow of the rivers Elbe and Weser up to the Dogger Bank, and a transect down-current from an abandoned drilling site. A Sediment Bioassay Group performed a wide variety of bioassays on sediment samples from these transects. Both solid phase and elutriate techniques were used for sediment testing (Chapman et al. 1992). The workshop provided a unique opportunity to compare the responses of frequently used North American and West

\footnotetext{
- Present address: Environment + Resource Technology Ltd Waterside House, 46 The Shore, Leith, Edinburgh EH6 6QV, United Kingdom
}

European infaunal amphipod species when exposed to identical sediment samples. The amphipod bioassays were performed at 4 laboratories: the U.S. Environmental Protection Agency Research Laboratory, Newport, Oregon, USA (EPA), the EVS Consultants Laboratory, North Vancouver, BC, Canada (EVS), the Water Research Centre, Medmenham, UK (WRC) and the Rijkswaterstaat Tidal Waters Division laboratory, Middelburg, The Netherlands (TWD).

\section{MATERIALS AND METHODS}

Sediment sampling, splitting and distribution. The workshop was based in Bremerhaven, Germany, at the Alfred Wegener Institute (AWI) for Polar and Marine Research, and was supported by a fleet of 8 research vessels. Samples for the sediment bioassays were collected on the Drilling Site transect on March 13,14 and 15,1990 . The 7 stations were located on a transect in 
the residual current direction of $066^{\circ}$ from the drilling site (drilling location F18-9, coordinates $54^{\circ} 06^{\prime} 15.0^{\prime \prime} \mathrm{N}$, $04^{\circ} 45^{\prime} 33.0^{\prime \prime} \mathrm{E}_{\text {; }}$ see Daan et al. 1992). The stations were designated $A$ to $G$, with distances of $0,125,250$, $500,1000,2000$ and $5000 \mathrm{~m}$ from the point source (Stebbing \& Dethlefsen 1992). At each station 3 replicate sediment samples were collected. The samples were initially collected with a $0.13 \mathrm{~m}^{2}$ Reineck box corer, but due to bad weather conditions the sediments from Stns B \& C had to be collected with a $0.10 \mathrm{~m}^{2}$ Van Veen grab. For each station replicate about $5 \mathrm{l}$ of sediment was removed from the upper $20 \mathrm{~cm}$ layer of 3 different grabs and packed in large polyethylene bags. Samples were kept cool at about $6{ }^{\circ} \mathrm{C}$. After landing, the samples were transported to the TWD field laboratory 'Jacobahaven' where they were prepared for distribution on March 17. The samples were removed from the plastic bags and homogenized in stainless steel bowis. The total amount of sediment was split into subsamples which were double packed in clean polyethylene bags, labelled and packed in coolboxes under blue ice for shipping. Residual sediment from the subsamples used for the Bathyporcia sarsi test were frozen for chemical analysis.

Sediment samples from the German Bight transect were collected on March 27, 28 and 29, 1990. The gradient is situated between $54^{\circ} \mathrm{N} 07^{\circ} 50^{\prime} \mathrm{E}$ and $56^{\circ} \mathrm{N}$ $03^{\circ} 24^{\prime} \mathrm{E}$ (see Stebbing \& Dethlefsen 1992). Stns 1, 2 \& 3 are close to the Elbe and Weser estuaries, $\operatorname{Stn} 9$ is the most northwestern, over the east end of the Dogger Bank. The gradient was sampled by 2 vessels, each starting at a different end of the gradient, which led to the unplanned double sampling of Stn 6. These samples were coded $6 i$ and 60 , referring to the inner and outer sampling series. For the inner series, Stn 1 through to Stn $6 \mathrm{i}, 4$ station replicates were collected. For the outer series, Stn 60 through to Stn 9, 3 station replicates were collected. Each station replicate consisted of samples composed of the upper 4 to $10 \mathrm{~cm}$ layers of multiple Van Veen grabs. The sediments were packed in polyethylene bags and stored in refrigerators. Samples were split and distributed on March 29 at AWI, Bremerhaven, in the same way as were the drilling site samples. From these samples subsamples were taken and frozen for subsequent chemical analysis. The bioassay samples were transported to the participating laboratories in coolboxes on blue ice. All testing was conducted within 3 wh of collection.

Sediment chemical analysis. The sediments were analysed for a number of chemicals in unfractionated samples and in the $<63 \mu \mathrm{m}$ fraction. Detailed information and full data are provided by Cofino et al. (1992). The sediment samples used for unfractionated analysis were subsamples from the same batches as those used for the bioassays described here. The expected con- tamination gradient along the drilling site transect was not reflected in the chemical analysis (see Rumohr \& Schomann 1992). Heavy metal and hydrocarbon concentrations were of comparable low levels at all stations. The sediment chemistry of the German Bight Transect clearly showed a decreasing concentration gradient offshore for heavy metals and hydrocarbons.

Sediment grain size analysis. Sand/silt/clay fractions and loss on ignition (LOI) were determined at EPA for a composite sample of all replicates at each station (Chapman et al. 1992). For the drilling site transect all samples were nearly identical: 85/8/7\% and $2 \%$ LOI. The German Bight transect samples ranged from $7 / 57 / 36 \%$ and $11 \%$ LOI at Stn 1 to $100 / 0 / 0 \%$ and $0.4 \%$ LOI at Stn 9 .

Bioassay test species. Three different species of infaunal amphipods were used in testing. The North American species Rhepoxynius abronius is a phoxocephalid amphipod inhabiting clean sands on the continental shelf and in the higher salinity portions of estuaries of the NE Pacific coast. It is found in lower intertidal zones, although it is typically a subtidal species from shallow waters. This species is a predator on soft-bodied benthic invertebrates (Swartz et al. 1985). Corophium volutator is a tube-dwelling, surface deposit feeder from intertidal mudflats in the North Atlantic region (Lincoln 1979). Bathyporeia sarsi inhabits well-sorted, wave-swept sandy beaches and intertidal sand flats. It feeds on organic material between and adhering to sand particles. It does not build tubes and is therefore dependent on the interstitial water for its oxygen supply. This species has been recorded in the Atlantic and North Sea coastal areas from France up to Norway (Lincoln 1979). R. abronius was used by 2 participating laboratories, EPA and EVS. C. volutator was used by WRC, and B. sarsi was used by TWD

Test methods. The bioassay method used for the amphipod tests is based on the procedures described by Swartz et al. (1985) and Chapman \& Becker (1986). All test species were collected from field populations living in unpolluted areas. The test set-up consisted of 11 glass beakers, with a layer of about $2 \mathrm{~cm}$ of test sediment covered by filtered seawater. The seawater was aerated and the beakers were kept at constant temperature and light conditions. Test temperature for Rhepoxynius abronius was $15^{\circ} \mathrm{C}\left( \pm 1^{\circ}\right)$, for Corophium volutator $14^{\circ} \mathrm{C}\left( \pm 1^{\circ}\right)$ and for Bathyporeia sarsi ambient temperature $\left(10^{\circ} \mathrm{C} \pm 1^{\circ}\right.$ for the drilling site samples, $14{ }^{\circ} \mathrm{C} \pm 1^{\circ}$ for the German Bight samples). After a 2 to $5 \mathrm{~d}$ acclimatisation period the required number of test animals was randomly selected and introduced into the test beakers. The Corophium volutator test was performed with 10 individuals per test beaker; the other tests used 20 individuals per test beaker. 
EVS set up 2 laboratory replicates per replicate sediment sample for the drilling site series, but did not prepare laboratory replicates for the German Bight series. Control sediments were tested in 6 replicates. EPA did not run laboratory replicates; negative controls were tested in 5 replicates. WRC and TWD ran 2 laboratory replicates on each station replicate. WRC used 6 negative control replicates; TWD had 3 controls for the drilling site series and 6 for the German Bight series. Because of a priori expectations of relatively high toxicity, the test was also conducted on diluted sediment from Stns 1, $2 \& 3$ by EPA. The dilutions represented $50 \%, 10 \%$ and $1 \%$ mixtures of German Bight sediment with sediment from the Rhepoxynius abronius collection site.

All tests had an exposure time of $10 \mathrm{~d}$. During the test period $\mathrm{pH}, \mathrm{O}_{2}$, temperature and salinity were monitored. At EPA and EVS avoidance behaviour of Rhepoxynius abronius was determined by daily counts of numbers of amphipods that had emerged from the sediment. For Corophium volutator the cumulative number of emerged individuals apparently immobilised was recorded every $48 \mathrm{~h}$.

After the exposure period, the test animals were sieved from the sediment and the survivors were counted. Except for Corophium volutator, which is a tube-builder, the surviving animals were transferred into beakers with clean control sediment to count the number of animals which were not able to rebury, which is used as a measure of sublethal stress (Swartz et al. 1985).

Negative/positive controls. All laboratories used a clean reference sediment for conducting negative controls, consisting of the native sediment inhabited by the test species. The maximum acceptable control mortality is $10 \%$. Positive controls were used for monitoring test animal conditions. EPA conducted a $96 \mathrm{~h}$ water-only $\mathrm{LC}_{50}$ test with $\mathrm{CdCl}_{2}$ as a reference toxicant. EVS used the same technique with NaPCP as a reference toxicant. Corophium volutator was exposed to a naval dockyard sediment known to be contaminated. No positive control measurements were made for Bathyporeia sarsi.

Statistical analysis. Significant differences in survival and sublethal stress between the test sediments and the control sediments were determined by ANOVA in combination with Dunnett's Multiple
Comparisons Test (Zar 1984). For those bioassays in which both field and laboratory replicates were tested, the means of laboratory replicates were used as data points.

\section{RESULTS}

\section{Survival}

Survival data for the drilling site transect sediments are presented in Table 1 and Fig. 1. All test results had acceptable survival in the controls, ranging from 90 to $100 \%$. Rhepoxynius abronius showed a reduced survival only at Stn A. At EPA this mortality was considered statistically significant. At EVS survival of $R$. abronius at $\operatorname{Stn} \mathrm{A}$ was lower than at the other stations, but not significantly so. Corophium volutator suffered significant mortality at Stns A, B \& C, with survival at Stn A below $50 \%$. Survival in Bathyporeia sarsi was comparable to $R$. abronius at EPA; at Stn A a statistically significant negative response was observed. Sediment from Stn A had a negative effect on all test species; the other drilling site sediments caused no adverse effects, except for $C$. volutator at Stns B \& C.

Survival data for the German Bight sediments are presented in Table 2 and Fig. 2. All test results met the required control survival, ranging from 90 to $98 \%$. The EPA and EVS Rhepoxynius abronius bioassays showed identical responses. Survival was significantly affected only in sediment samples from Stn 1 . The diluted sediments of Stns $1,2 \& 3$ tested by EPA were not acutely toxic, as mortality was below $10 \%$ in all treatments. The Corophium volutator test resulted in significantly lowered survival in 5 out of 10 test sediments. Analysis of variance on the Bathyporeia sarsi test results indicated that there were no significant differences between the test sediments and the control.

Table 1. Mean survival percentages of amphipod species on drilling site sediments. Asterisks indicate significant differences from the control sediments $(p<0.05)$. Standard error is given in brackets. For number of replicates, see text

\begin{tabular}{|c|c|c|c|c|}
\hline Stn & $\begin{array}{c}\text { Rhepoxynius } \\
\text { abronius } \\
\text { EPA }\end{array}$ & $\begin{array}{c}\text { Rhepoxynius } \\
\text { abronius } \\
\text { EVS }\end{array}$ & $\begin{array}{l}\text { Corophium } \\
\text { volutator } \\
\text { WRC }\end{array}$ & $\begin{array}{c}\text { Bathyporeia } \\
\text { sarsi } \\
\text { TWD }\end{array}$ \\
\hline A & $66.50(15.91)^{\bullet}$ & $76.65(6.52)$ & $45.00(3.81)^{\circ}$ & $88.35(2.19)^{\circ}$ \\
\hline B & $93.35 \quad(3.35)$ & $91.65(4.42)$ & $70.00(5.77)^{\circ}$ & $97.50(1.44)$ \\
\hline C & $96.65 \quad(3.35)$ & $92.50(2.89)$ & $58.00(3.64)^{\circ}$ & $95.85(2.19)$ \\
\hline $\mathrm{D}$ & $95.00 \quad(2.89)$ & $93.35(5.46)$ & $71.70(0.84)$ & $95.00(1.44)$ \\
\hline E & $100.00 \quad(0.00)$ & $95.00(0.00)$ & $80.00(2.89)$ & $94.00(1.67)$ \\
\hline $\mathrm{F}$ & $96.65 \quad(3.35)$ & $88.35(9.30)$ & $90.00(1.44)$ & $95.85(3.00)$ \\
\hline $\mathrm{G}$ & $93.35 \quad(3.35)$ & $93.35(3.35)$ & $86.70(1.67)$ & $94.15(0.87)$ \\
\hline Control & $98.00 \quad(1.99)$ & $94.15(1.54)$ & $90.00(2.25)$ & $100.00(0.00)$ \\
\hline
\end{tabular}


Table 2. Mean survival percentages of amphipod species on German Bight sediments. error is given in brackets. For number of replicates, see text

\begin{tabular}{|lcccc|}
\hline $\begin{array}{c}\text { Stn } \\
\text { Rhepoxynius } \\
\text { abronius } \\
\text { EPA }\end{array}$ & $\begin{array}{c}\text { Rhepoxynius } \\
\text { abronius } \\
\text { EVS }\end{array}$ & $\begin{array}{c}\text { Corophium } \\
\text { volutator } \\
\text { WRC }\end{array}$ & $\begin{array}{c}\text { Bathyporeia } \\
\text { sarsi } \\
\text { TWD }\end{array}$ \\
\hline 1 & $83.75(4.28)^{\circ}$ & $46.25(11.43)^{\circ}$ & $68.30(3.00)^{*}$ & $85.00(1.44)$ \\
2 & $92.50(4.80)$ & $81.25(7.75)$ & $68.30(3.00)^{*}$ & $86.65(0.84)$ \\
3 & $88.35(3.83)$ & $86.25(3.75)$ & $55.00(8.03)^{*}$ & $90.85(5.08)$ \\
4 & $97.50(1.45)$ & $86.25(4.73)$ & $83.30(0.87)$ & $80.85(0.84)$ \\
5 & $100.00(0.00)$ & $93.75(2.40)$ & $75.00(0.00)$ & $94.15(1.67)$ \\
$6 \mathrm{i}$ & $93.75(3.15)$ & $90.00(2.40)$ & $71.70(2.19)$ & not tested \\
60 & $100.00(0.00)$ & $81.65(4.42)$ & $68.30(0.84)^{\circ}$ & $94.15(5.83)$ \\
7 & $95.00(2.89)$ & $90.00(2.89)$ & $76.70(2.19)$ & $86.65(5.08)$ \\
8 & $97.50(2.05)$ & $93.35(3.35)$ & $88.30(3.64)$ & $92.50(1.44)$ \\
9 & $98.35(1.67)$ & $91.65(1.67)$ & $66.70(4.16)^{\circ}$ & $95.85(2.19)$ \\
Control & $98.00(1.23)$ & $96.65(1.06)$ & $93.30(1.67)$ & $90.00(4.99)$ \\
\hline
\end{tabular}
Asterisks indicate significant differences from the control sediments $(p<0.05)$. Standard

Stn 1 and one in Stn 2 sediment. Bathyporeia sarsi showed a pronounced effect in the reburial test with the drilling site sediments: $28 \%$ of the surviving Stn A amphipods did not rebury within $1 \mathrm{~h}$ in clean control sediment. For the German Bight sediments, the percentage of non-stressed individuals was calculated by subtracting the number of individuals which did not rebury in control sediment from the total number surviving. Numbers of nonstressed amphipods were then statistically analysed,

\section{Reburial}

The reburial test for Rhepoxynius abronius did not show significant responses. At EVS the percentage of surviving amphipods able to rebury in clean sediment ranged from 84 to $100 \%$. At EPA only 2 of all the surviving animals did not rebury after exposure: one in
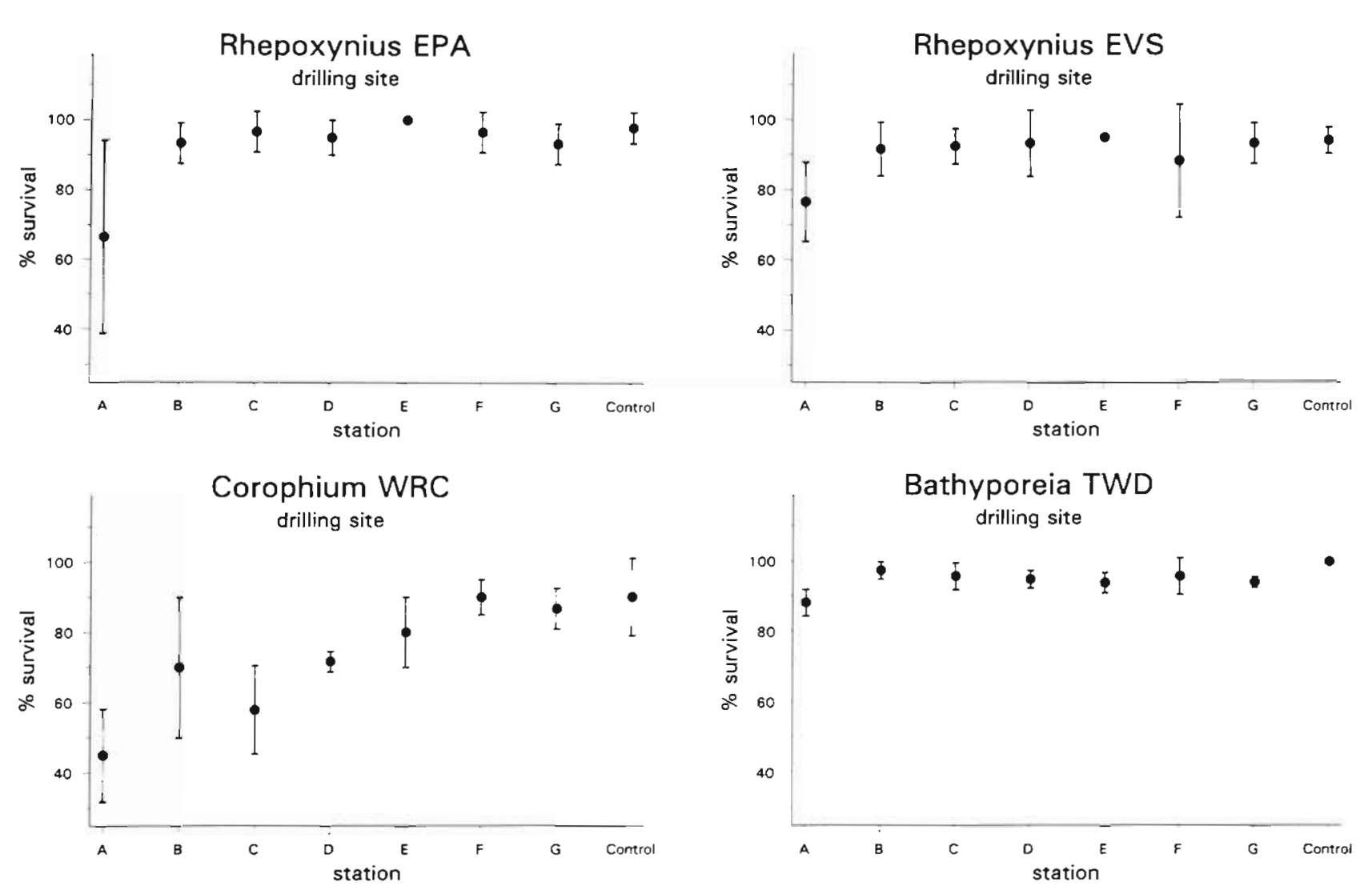

The number of amphipods on the sediment surface per jar per day (out of a maximum of 20) was counted the $B$. sarsi test.

\section{Avoidance and immobilisation}

Fig. 1. Survival percentages in amphipod bioassays on drilling site sediments. Mean values per station with standard deviations 
for Rhepoxynius abronius at EVS and EPA. Avoidance ranged from 0.1 to 0.6 on the drilling site sediments and from 0 to 0.9 on the German Bight sediments. These numbers were very low and did not show any correlation with the other endpoints. For Corophium volutator, first observations of emergence and immobilisation were recorded on the third day of exposure in the Strn A sediments. At the end of the test, $25 \%$ of the Stn A test animals were apparently immobilised. Other drilling site and German Bight samples did not cause these sublethal effects on $C$. volutator.

\section{Negative/positive controls}

All test results were acceptable based on $90 \%$ or more survival in the control sediments. The cadmium $\mathrm{LC}_{50}$ 's for Rhepoxynius abronius at EPA were $0.94 \mathrm{mg} \mathrm{l}^{-1}$ (95\% confidence interval [Cl] $=0.76$ to $1.16 \mathrm{mg} \mathrm{l}^{-1}$ ) in the drilling site test and $0.84 \mathrm{mg} \mathrm{l}^{-1}$ $\left(95 \% \mathrm{CI}=0.52\right.$ to $1.34 \mathrm{mg} \mathrm{l}^{-1}$ ) in the German Bight test. These values are within the acceptable range for quality control measurements: 0.68 to $1.25 \mathrm{mg} \mathrm{l}^{-1}$ (ASTM 1991). The NaPCP $\mathrm{LC}_{50}$ values measured at EVS for $R$. abronius were $240 \mathrm{\mu g} \mathrm{l}^{-1}$ in the drilling site test and $320 \mu \mathrm{g} \mathrm{l}^{-1}$ for the German Bight test. The first

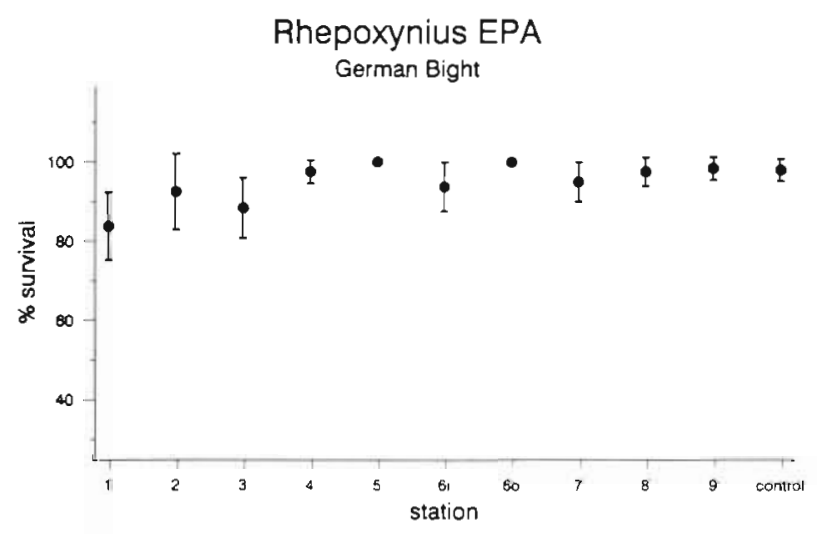

Corophium WRC

German Bight

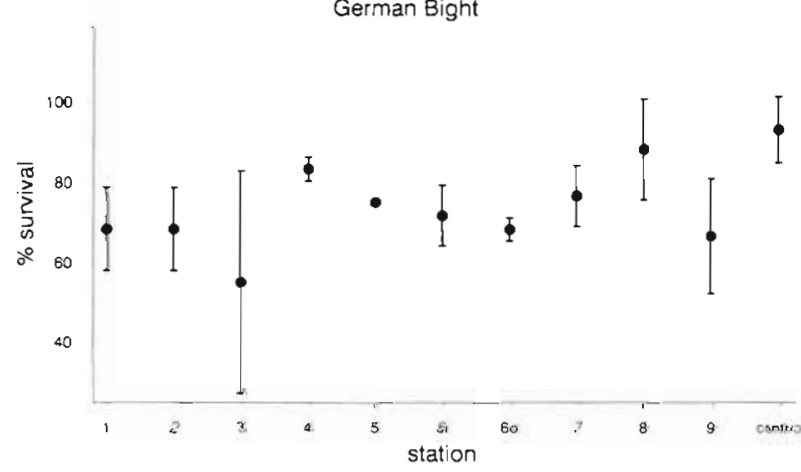

value was below, and the second within the recommended acceptable limits of 300 to $390 \mu \mathrm{g} \mathrm{l}^{-1}$ (Chapman \& Becker 1986), suggesting that the first series of amphipods was slightly more sensitive than is generally the case. Mean mortality of Corophium volutator on the contaminated reference sediment was $35 \%$ for the drilling site series and $42 \%$ for the German Bight series. There are no previous, comparative data available, but the results were considered to be of acceptable comparability.

\section{DISCUSSION}

\section{Sediments}

Based on the bioassay results, there was no clear pollution gradient for either the drilling site or the German Bight transect. Toxic responses were apparent clearly only at the innermost stations of each transect (Stns A \& 1).

For the drilling site the low response of the test organisms and the low levels of contaminants may be explained by observations from REMOTS camera pictures of in situ sediment depth profiles taken at the same stations during the workshop (Rumohr \&
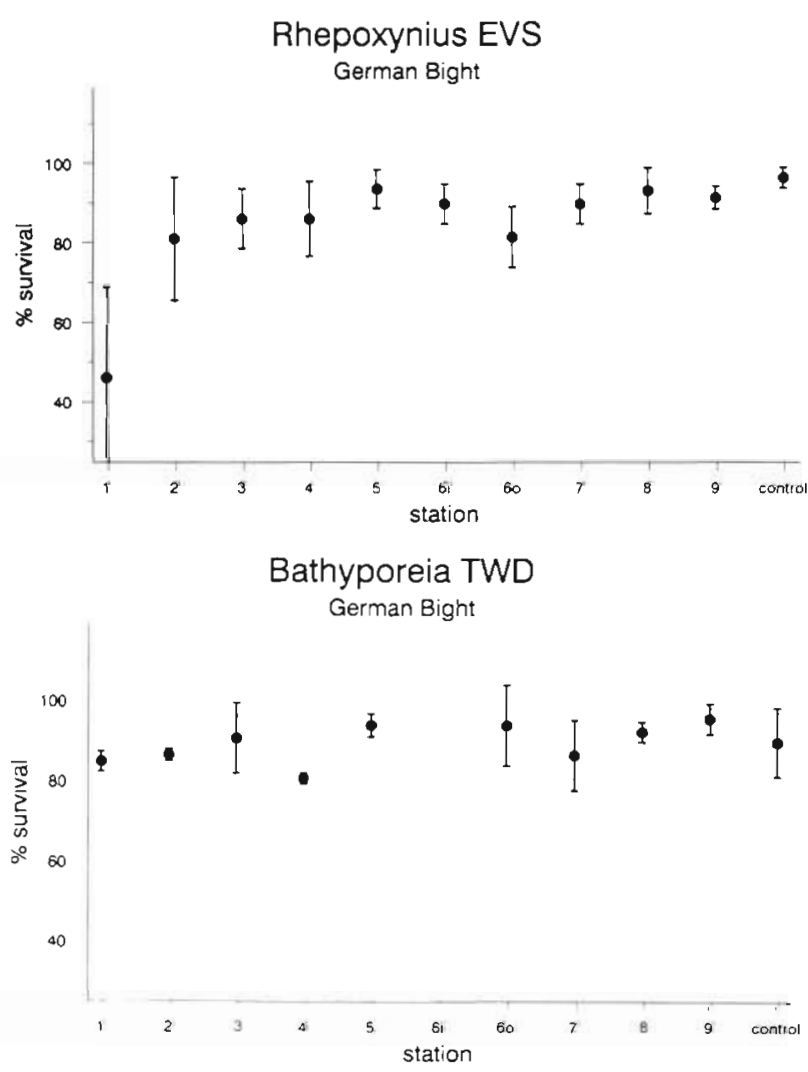

Fig. 2. Survival percentages in amphipod bioassays on German Bight sediments. Mean values per station with standard deviations 
Schomann 1992). These pictures show a 10 to $15 \mathrm{~cm}$ layer of clean sand on top of a black, obviously contaminated, layer at the innermost drilling site stations. This clean sand may have been deposited on the area during severe storms in the weeks before the workshop was held. The bioassay responses to Stn A sediments cannot be explained by the sediment analytical chemistry (see Cofino et al. 1992). It is remarkable that both Corophium volutator and Bathyporeia sarsi show clear signs of narcotization with exposure to the sediment from this station. It is possible that volatile, or fast diffusing compounds have penetrated the recently deposited sands, thus causing the observed effects on the amphipods. These compounds might not have been reflected in the analytical data.

The bioassay responses to the German Bight Stn 1 samples clearly correlate with the high levels of contaminants. The negative effects of Stn 1 sediments on Rhepoxynius abronius could be due in part, to an effect of the small grain size of this sediment (DeWitt et al. 1988). Conversely, the coarse sand and low organic carbon content of the Stn 9 sediment may have strengthened any negative effects on Corophium volutator exposed to sediment from this station. Although C. volulator does not show mortality on the coarse sediments of the outer drilling site stations, it has been documented that it can suffer negative effects from exposure to coarse sand (J. Van de Wassenberg pers. comm.).

\section{Test species}

Both laboratories that used Rhepoxynius abronius generated comparable results. Thus, this exercise gives a reliable intercalibration for this species, confirming similar conclusions in a more comprehensive interlaboratory comparison (Mearns et al. 1986). Bathyporeia sarsi appears to be less sensitive than $R$. abronius when only mortality is taken into account. When reburial as a second endpoint is incorporated into the results, the sensitivity of the bioassay improves. It is apparent that the reburial endpoint is much more useful for $B$. sarsi than for $R$. abronius. Long et al. (1990) state that avoidance and reburial appear to be insensitive and variable endpoints for $R$. abronius. It has been observed previously that on oil-contaminated sediments the reburial endpoint for $B$. sarsi gives extra information on the sediment quality (Van den Hurk 1990). The Corophium volutator test indicates that it is the most sensitive of the 3 species tested here Survival of $C$. volutator was significantly reduced in more sediment samples than any of the other species tested. However, other experiments in which $C$. volutator has been compared to $B$. sarsi have shown that Corophium is generally less sensitive to sediment pollution than B. sarsi (Van den Hurk unpubl. data).

\section{Test method}

The test method was based on the procedures described by Swartz et al. (1985). The main differences in test design between the participating laboratories lay in the use of laboratory replicates, the number of animals per test chamber, the use of different endpoints and the use of positive controls. The use of laboratory replicates for each field replicate requires more effort in performing the test, but is useful when the field replicates show considerable differences. When handling the drilling site sediments, clear differences in oil content could be observed between the field replicates. This patchiness in sediment contamination was considered when making the decision to run laboratory replicates. However, in the case of the North Sea sediments tested in this study, the use or omission of laboratory replicates did not influence the final results.

The number of animals per test chamber is of importance for the power of the test. Twenty animals per test chamber is generally considered desirable; for smaller numbers of animals, differences between the treatments have to be large to yield statistical significant differences. For Rhepoxynius abronius there is a $75 \%$ probability of detecting a significant difference when the difference in mean survival between control and test sediment is 2.8 in a test set-up with 5 replicates per treatment and 20 amphipods per replicate (Swartz et al. 1985). For Corophium volutator only 10 animals were used per test chamber. It is clear that in the tests described here, this relatively low number of test animals per laboratory replicate did not influence the power of the tests, as with $C$. volutator the largest number of toxic samples were recognised.

Not all endpoints were measured by all laboratories. Mortality was determined by all participants, avoidance and reburial were not. For Rhepoxynius abronius, avoidance and reburial gave no extra information in this study. Nevertheless, in some cases avoidance may be a useful measure, as within the range of 76 to $87 \%$ survival it is not possible to determine whether sediment samples are toxic or not (Mearns et al. 1986). Avoidance behaviour can give useful extra information in those cases. It is clear from this study and from previous work by van den Hurk (1990) that reburial of Bathyporeia sarsi is a useful test end-point.

The use of positive controls is necessary to check the quality of the test organisms. The EVS $\mathrm{LC}_{50}$ for the drilling site series indicated increased sensitivity of the test animals. However, this apparently did not influence the results, since survival of Rhepoxynius abronius exposed to Stn A sediment was actually higher in 
the EVS test than in the EPA test. For interlaboratory comparisons the use of identical reference toxicants would be useful. In the present study, participating laboratories used different reference toxicants, or none at all. Clearly, standardisation is desirable not just in North America (e.g. ASTM 1991) but between North America and Europe as well.

\section{CONCLUSIONS}

The drilling site and German Bight transects did not provide the ideal opportunity to compare the sensitivity of North American and West European marine amphipod sediment bioassays. Most sediments on both transects did not cause significant reductions in survival and even when toxicity was significant, the mean reduction in survival was only $30 \%$. However, we are encouraged that all 4 tests showed either significant effects (mortality or reburial) or minimum survival for sediments from Stn A. Also, 3 of the 4 tests showed significant effects from sediments collected at Stn 1. Significant effects at some of the other 15 stations in this survey were only detected by the Corophium volutator sediment toxicity test.

Acknowledgements. The Dutch contribution to studies presented here was part of the project Stresspar $* 7$, funded by Rijkswaterstaat, Tidal Waters Division, The Netherlands. We thank Dr A. C. Smaal for supplying laboratory facilities at the TWD field station 'Jacobahaven' The UK studies were conducted at the Medmenham laboratory of WRC, and formed part of a programme of work funded by the UK National Rivers Authority. The permission of the NRA to publish the results of this work is gratefully acknowledged. EVS Consultants provided in-house support for their aspects of these studies. This is contribution No. N-186, U.S. Environmental Protection Agency, Environmental Research Laboratory, Newport, Oregon. External peer review was provided by Michele Redmond (SAIC), Walter Berry (SAIC) and Bruce Boese (U.S. EPA).

\section{LITERATURE CITED}

ASTM (1991). Standard guide for conducting 10-day static sediment toxicity tests with marine and estuarine amphipods. Designation: E 1367-90. In: Annual Book of ASTM
Standards, Water and Environmental Technology. Vol. 11.04. American Society for Testing and Materials, Philadelphia, 1052-1075

Chapman, P. M., Becker, S. (1986). Recommended protocols for conducting laboratory bioassays on Puget Sound sediments. Final Report. TC-3991-04. U.S. EPA, Seattle, WA

Chapman, P. M., Swartz, R. C., Roddie, B., Phelps, H. L., van den Hurk, P., Butler, R. (1992). An international comparison of sediment toxicity tests in the North Sea. Mar. Ecol. Prog. Ser. 91. 253-264

Cofino, W. P., Smedes, F., de Jong, S. A., Abarnou, A., Boon, J. P., Oostingh, I., Davies, I. M., Klungsøyr, J., Wilhelmsen, S., Law, R. J., Whinnett, J. A., Schmidt, D., Wilson, S. (1992). The chemistry programme. Mar. Ecol. Prog. Ser 91: $47-56$

Daan, R., van het Groenewoud, H., de Jong, S. A., Mulder, M (1992). Physico-chemical and biological features of a drilling site in the North Sea, 1 year after discharges of oil-contaminated drill cuttings. Mar. Ecol. Prog. Ser. 91: 37-45

DeWitt, T. H., Ditsworth, G. R., Swartz, R. C. (1988). Effects of natural sediment features on survival of the phoxocephalid amphipod, Rhepoxynius abronius. Mar. environ Res. 25: 99-124

Lincoln, R. J. (1979). British marine Amphipoda: Gammaridea. British Museum (Natural History), London

Long, E. R., Buchman, M. F., Bay, S. M., Breteler, R. J., Carr, R. S., Chapman, P. M., Hose, J. E., Lissner, A. L., Scott, J., Wolfe, D. A. (1990). Comparative evaluation of five toxicity tests with sediments from San Francisco Bay and Tomales Bay, California. Environ. Toxicol. Chem. 9 1193-1214

Mearns, A. J., Swartz, R. C., Cummins, J. M., Dinnel, P. A. Plesha, P., Chapman, P. M. (1986). Inter-laboratory comparison of a sediment toxicity test using the marine amphipod, Rhepoxynius abronius. Mar. environ. Res. 19: 13-37

Rumohr, H., Schomann, H. (1992). REMOTS sediment profiles around an exploratory drilling rig in the southern North Sea. Mar. Ecol. Prog. Ser. 91: 303-311

Stebbing, A. R. D., Dethlefsen, V. (1992). Introduction to the Bremerhaven Workshop on Biological Effects of Contamination. Mar. Ecol. Prog. Ser. 91: 1-8

Swartz, R. C., DeBen, W. A., Phillips, J. K., Lamberson, J. O., Cole, F. A. (1985). Phoxocephalid amphipod bioassay for marine sediment toxicity. In: Cardwell, R. D., Purdy, R., Bahner, R. C. (eds.) Aquatic toxicology and hazard assessment: seventh symposium. ASTM STP 854, p. 284-307

van den Hurk, P. (1990). Bioassays with oyster larvae and Bathyporeia sarsi (Crustacea, Amphipoda) on North Sea sediments from Drilling Area L-5-5. Report 90.18. Bureau Waardenburg bv, Culemborg (In Dutch)

Zar, J. H. (1984). Biostatistical analysis, 2nd edn. PrenticeHall, Englewood Cliffs, NJ 